Bond University

Research Repository

\title{
The State of Feature Writing Today
}

Ricketson, Matthew; Graham, Caroline

Published in:

Asia Pacific Media Educator

DOI:

$10.1177 / 1326365 \times 18811528$

Licence:

Other

Link to output in Bond University research repository.

Recommended citation(APA):

Ricketson, M., \& Graham, C. (2018). The State of Feature Writing Today. Asia Pacific Media Educator, 28(2), 205-217. https://doi.org/10.1177/1326365X18811528

\section{General rights}

Copyright and moral rights for the publications made accessible in the public portal are retained by the authors and/or other copyright owners and it is a condition of accessing publications that users recognise and abide by the legal requirements associated with these rights.

For more information, or if you believe that this document breaches copyright, please contact the Bond University research repository coordinator. 


\section{The state of feature writing today}

Commentary for Asia-Pacific Media Educator - October 2018

\section{By Matthew Ricketson and Caroline Graham}

Matthew Ricketson, Professor of Communication (School of Communication and Creative Arts), Deakin University.

Matthew.ricketson@deakin.edu.au

c/- Deakin University Faculty of Arts and Education

221 Burwood Highway,

Burwood,

Victoria, 3125

(03) 92468833

Caroline Graham, Senior Teaching Fellow (Communication and Creative Media), Bond University.

cgraham@,bond.edu.au

c/- Bond University Faculty of Society and Design,

Gold Coast,

Queensland, 4229

(07) 55952538

Abstract: This commentary considers the changing nature of feature writing within the contexts of: multimedia tools, the online publishing landscape, shrinking newsrooms, changing revenue models, freelance markets, audience and story analytics and journalism education.

Keywords: feature writing, online, multimedia, analytics, journalism education, print media. 


\section{The state of feature writing today \\ Commentary for Asia-Pacific Media Educator - October 2018}

The Irish playwright and philosopher, George Bernard Shaw, once described newspapers as a device "unable to distinguish between a bicycle accident and the collapse of civilisation". In much the same way, peril awaits the journalism educator seeking to distinguish between the latest micro-trend in the unceasing flow of content that is the modern media and significant changes in journalistic practice.

Look at journalism from six decades ago and you would think changes have been massive and easily discerned, an observation supported by the precede, or standfirst, for an article written by Gavin Souter for The Sydney Morning Herald in 1960 (in Hurst, 1998, pp. 88-89). "This is a series of articles by a staff correspondent who has just returned from a visit to Australian and Dutch New Guinea. In them, he discusses his conversations with, and impressions of, the emerging native elite in both countries." So stiff, so paternalistic to read today and yet Souter's journalism was regarded as exemplary, winning a Walkley award. Yet, look at the Walkley feature writing category three years previously, and the winning piece from 1957 is quite different in style and approach. Selwyn Speight went to the steel-making and mining town of Wollongong to assess first-hand the difficulties many post-war migrants experienced adjusting to life in their new homeland. He spent an evening in a local pub and his clear-eyed description brought the reader into the hotel with him, where Italians, Dutch, Yugoslavs, Czechs, Lithuanians and others mixed awkwardly with “old Australians” (Speight in Hurst, pp. 79-82). 
With this caution in mind about the difficulties of discerning meaningful trends, let's ask some questions about developments in the world of feature writing in 2018 . We have drawn on our work in Writing Feature Stories (2017) and on our more recent experience and reading.

\section{How has feature writing evolved?}

Without a doubt the advent of the internet has had a significant impact on modern journalism. In the introduction to the first edition of Writing Feature Stories (2004, pp. ix-x), Matthew tried to convey how confusing it is for young journalists to be asked to write features, which contain some of the creativity and licence of novelwriting but remain tethered to the real world and to deadlines. The internet was then in its first decade and Facebook was just beginning; it was not yet "eating the world", as Emily Bell put it in 2016 (n.p.).

Bell's influential article was published while Matthew, with co-author, Caroline, was updating Writing Feature Stories. The internet's impact was unavoidable; the book's opening sentence (p. 1) was: "One of the great things about the internet is that it's made everyone a writer; one of the terrible things about the internet is that it's made everyone a writer". Teasing out the threads of that paradox is central to the book.

Many of the narrative techniques that govern the writing of good feature stories remain unchanged. Even the Pulitzer Prize committee, in defining the scope of its feature writing award, acknowledges that narrative is key: while it allows feature writers to use any tool available to them to tell their stories, prime consideration is 
given to the quality of the writing and the originality of the story (Topping, 2014). As Brian Carroll says in his book Writing for Digital Media (2010) 'the premium on good writing has not changed'.

However, some shifts are distinct. The most obvious development in the evolution of feature stories is the proliferation of multimedia storytelling tools, made possible by the shift to digital (or hybrid print/digital) publishing. A feature writer-or indeed, a team of reporters, photographers, illustrators, data scientists, web designers and even marketers - can now integrate video, photographs, animations, interactive data visualisations, infographics and more into rich, evocative story packages. Early multimedia features (like the much-lauded 2012 New York Times feature 'Snow fall') were rare and costly endeavours, representing strategic investments for established newsrooms. However, the technology required to create such content is increasingly accessible, to the extent that an enterprising journalist with no coding or web design experience could use open-source or web-based software to create and publish a professional multimedia package quite easily, even on a tight deadline.

It is true that not all of these multimedia techniques are new. In the 1850 s Florence Nightingale, horrified by the number of soldiers who lost their lives to preventable disease during the Crimean War, collected data about hygiene practices, rates of death and mortality causes. Her sophisticated data visualisations_-including her augmented pie chart, the coxcomb - were presented to the health department to successfully change conditions in hospitals and would fit as comfortably on the BBC's data pages now as any contemporary data-driven reporting (Rogers, 2010). Nevertheless, Annie Schugart's wrap-up of the best interactive journalism features of 2017 is evidence of 
the extent to which multimedia elements have evolved in recent years; they are no longer mere bells and whistles used to augment written work but, rather, can represent approaches to the genre that simply would not have been possible in print narratives. Schugart's examples range from light-hearted features, such as The Washington Post's real-time compilation of Instagram photos of \#eclipse2017 or CNN's Love Story: Voicemails of love from around the world through to more serious fare, like Reuters' interactive illustration of life in the Rohingya refugee camps of Bangladesh. And in the meantime, multimedia tools are increasingly being mobilised to build trust, credibility and transparency, and as a means of crowdsourcing verification on published stories. ProPublica's 'Explore Sources' button, for example, allows a reader to see the evidence behind every single allegation in a story, through highlighting claims and linking to primary source documents.

Just as the boundaries between newspapers, magazines and online platforms have blurred to the point of disintegration, it is increasingly common for feature writers to cross into related creative fields. Australia's most experienced and respected investigative and feature journalists—names like Jane Cadzow, Helen Garner, Chloe Hooper, David Marr and Hedley Thomas — are now as likely to be penning long-form pieces for outlets like Quarterly Essay, releasing podcasts or writing non-fiction books or novels as they are to put their by-lines to news and magazine features. Decades of experience need not be a prerequisite for this kind of opportunity-in fact, examples of emerging writers who've garnered attention, opportunity and acclaim using feature writing as a starting point abound: Carly Findlay, Nayuka Gorrie, Anna Krien, Benjamin Law and Rosie Waterland, to name but a few who have used their 
feature-writing or blogging as a platform to develop books, TV series, longform essays and a one-woman stage show.

What these writers, however diverse, have in common is a shared fascination with narrative, a fresh voice, the ability to look beyond the obvious and return with an interesting perspective, a command of the material they're writing about (through research and experience) and a talent (honed through hard work and practice) for writing a great story. They're also skilled at tapping into the social and cultural movements of their time - picking up on trends, asking deep and difficult questions, and dissecting the world from strange perspectives until they find a way of making sense of it. These skills are, of course, timeless and will certainly endure as technology marches forward and publishing landscapes change, but the way they're deployed is likely to be specific to the current digital landscape, where there is an expectation that successful reporters must cultivate a public profile, navigate multiple platforms and projects at once, engage in conversation with readers (and detractors) and 'brand' themselves and their work.

And just as writers may navigate multiple platforms at once, so too do the stories they work on. Features have always had a place accompanying hard news stories and events but now they also inspire, supplement, contextualise and even advertise an enormous range of linked content. Recently, for example, journalists have found themselves the focus of a Hollywood intellectual property land-grab, with long-form features like the New York magazine's account of socialite scam-artist Anna Delvey or Daily Beast's story about a former cop who rigged the McDonald's Monopoly promotion, being optioned for film and television. The Guardian reports that 
production companies (for example, Page 1, which is co-founded by former New York Times magazine editor Hugo Lindgren) are finding ways to streamline the reporting and screenwriting processes, and in doing so are generating alternative revenue models for publications and writers: "Increasingly, literary non-fiction is thought of not as the product itself, but as a springboard for other products" (Nevins, 2018, n.p.). Whether this particular approach is sustainable remains to be seen; nevertheless, we suspect that one development likely to endure lies in a media landscape that is both fragmented and entangled. That is, readers' media consumption tends to be concentrated in particular areas and sources of interest while content is repurposed in different ways, for a range of revenue streams.

\section{Has the standard of feature writing improved or declined in the past decade or so? To what do you attribute this?}

A bit of both, which looks like dodging the question but actually goes to the multiplicity of elements that affect quality. Almost two decades ago Stephen Glover, a former editor of The Independent, wrote journalism was better and worse than it had been in bygone years. In Glover's assessment (1999, p. xii), newspapers in England were "less intimate, less treasured", though more comprehensive than they had been.

Newspapers are no longer the primary journalistic medium, even if predictions of their demise have so far proved untrue. That in itself hints at some of the complexity; feature writing has been able to improve by dint of the range of multimedia available to storytellers who can draw on audio, video, data graphics and interactivity, both in the ways stories are presented (and indeed researched) and in the cultivation of more 
equal relationships with readers. Predictions that citizen journalists would replace the need for companies to employ journalists have run aground, too, on the rocks of the reality that some journalistic skills, whether in finding information those in power don't want you to find, or cultivating sources or compelling writing, are simply not something that can be done by anyone.

If you are looking for good feature writing there is far more available than any one person can possibly read each day. We have provided suggestions for further reading, on pages 334 to 348 of Writing Feature Stories; this is supposed to be an edited highlights list, but it would probably take a student a good year reading every day to get through what is offered in those 15 pages. This is because the internet has shrunk space, enabling anyone to consume the world's media. The new communication technologies have also made accessible and, in many cases, searchable, masses of previously hard-to-find information, such as submissions to public inquiries or court rulings, while social media has made it easier for journalists to find prospective interviewees for stories. Google has made so much of the world's information retrievable at the click of a mouse that it seems fair to conclude the average level of verifiable facts in feature articles has improved. For instance, where sports broadcaster Bruce McAvaney, by dint of a well-stocked private library and exhaustive prepping, was once regarded as a repository of arcane sports statistics, now even the laziest broadcaster has access to a bank of such information. It has also made possible extraordinary investigative feats, exemplified by Eliot Higgins’ Bellingcat, a freely available website that combines geolocation and social media searches. Bellingcat has broken several important stories, most recently identifying as operatives linked to the secret service the two Russians who claimed to be tourists visiting Salisbury in 
England where Sergey and Yulia Skripal had been poisoned in early 2018

(https://www.bellingcat.com/news/uk-and-europe/2018/10/09/full-report-skripalpoisoning-suspect-dr-alexander-mishkin-hero-russia/).

As to the actual quality of writing in feature writing today, it is hard to make an overall assessment. Certainly, the quality of writing in pieces that win the nation's most prestigious journalism award, the Walkleys, are as good, if not better, than they have ever been. It is in the broad mass of feature writing that the quality - of the research and story ideas as well as the writing - is more variable and more susceptible to changes in the media industry that have impinged on the quality of features.

The inability of media companies in Australia to find a new business model to replace the one disrupted by the internet has led since 2011 to as many as 3000 journalists being laid off from the major employers, Fairfax Media, News Corp Australia and Network Ten, according to the Media Entertainment and Arts Alliance, the journalists' union (2018).

The impact of the loss of so much journalistic experience, both among senior writers and sub-editors, is hard to pinpoint because newspapers, magazines and online sites continue to be produced so a finer reading of quality is needed. The loss of subediting easy to spot in misspellings, typographical mistakes and simple factual errors, but whether a feature writer interviewed 12 people or 20 for their piece, for instance, is less clear. Two points are emerging, though; the loss of so much senior journalistic memory is being felt, both in the contextual thinness of many feature articles and 
among journalists in newsrooms who tell us they feel keenly the loss of experienced mentoring figures in the newsroom.

What does seem undeniable is that fewer journalists are producing more stories, across more media forms, every day. The news cycle no longer has the daily rhythm it had in the print era; it has even accelerated from the advent of the 24/7 new cycle which really referred to the rise of cable television news. As Sean Kelly, a former media adviser to prime ministers Kevin Rudd and Julia Gillard, now a political commentator, has written, the internet age puts a premium on creating masses of content all the time and the cheapest content to create is not news but opinion. "The beauty of opinions is that everyone's got one. The beauty of breaking news is that it doesn't have to be important or even difficult to get: it just has to have happened in the recent past" (Kelly in Murphy, 2018, p. 51). This means, according to Katharine Murphy, political editor of Guardian Australia, that the news cycle has become a "lot more breathless, and a lot more shouty" (p. 52).

It is not hard to see that in this always-on-at-fire-hydrant-strength journalistic environment the commodity that is most squeezed is time. Time to research and time to write. Journalism has always been a rushed business. The flowering in the $1960 \mathrm{~s}$ and 1970s of what was known as the New Journalism when newspaper and, especially, magazines' plump profitability enabled editors to give journalists weeks or even months to complete luxuriantly lengthy feature articles has long since disappeared. Editors and journalists know what can be produced when more time is available but time is just about the most precious commodity now. It is instructive that Eliot Higgins of Bellingcat began his online investigations when he had time on his 
hands after being laid off from his job, which is not to diminish the value of the original approach he brought to journalism from outside the newsroom (Keefe, 2013).

Journalists have even less time to reflect on these developments than in the past but Murphy is one who has been determined to do so, in regular features for Meanjin Quarterly and in her essay-book On Disruption, where she writes that as a senior parliamentary press gallery journalist, she is so saturated in content it dulls her senses. "Plugging in some days can make me feel physically ill, because I know constant input drains my capacity for original thought” (p. 94). We should be grateful for Murphy's commitment to candour as well as reflection, and perhaps reflect ourselves that while it is difficult for busy professional journalists like her to find the time to do so, such a habit is at least partly born of the re-ordering of the relationship between journalists and audiences.

\section{Has the focus of feature writing changed (that is, away from an investigation of complex issues in the news to coverage of personalities and lifestyle issues?) Is this a good or bad development?}

In a series of predictions about the future of news, The Washington Post editor Cory Haik suggested that 2015 would be the 'year of the reader' - and that the core focus of the next generation of newsrooms would be reader engagement. Haik's voice is just one in a chorus of experts who have spent the last few years buzzing about the 'game-changing' move towards audience-focused journalism. It isn't that the audience is a new conceit, or even a more important one; rather, the development of 
sophisticated web analytics offers newsrooms more detailed insight into what readers want. Newsrooms, editors and individual reporters can access data on a story's performance: page views, average reading/engagement times, location of reader, traffic sources/referrals, social actions, peak reading times, and more. The ability to quantify how content performs with readers has made sites like BuzzFeed, which might once have been considered low-brow, major players in the development of online news and features, and more traditional outlets like The New York Times and The Atlantic have certainly looked to them to develop audience engagement strategies.

Analytics are important, because while readers identify hard-hitting topics like national and local news, the economy, politics, health and science as the most important content to them (Reuters, 2014), annual lists of the most-read stories paints a very different picture of their reading preferences, which are invariably filled with quizzes, photo galleries and 'emotional poppers'. The Atlantic's Derek Thompson says of this distinction: “Ask audiences what they want and they'll tell you vegetables. Watch them quietly, and they'll mostly eat candy." Thompson has a theory about the gap between what readers say they want and what they actually consume: 'The more attention-starved we feel, the more we thirst for stimuli that are familiar. We like ice-cream when we're sad, old songs when we're tired, and easy listicles when we're busy and ego-depleted."

So, it might look like the focus of features, particularly online, has shifted. Soft, currency-based content is common online, and it's certainly visible in its nearuniversal popularity. The early years of online metrics raised legitimate concerns 
about the move towards 'populist', analytics-driven content creation but as analytics have grown more sophisticated, it has become more obvious that an individual reader's preferences will vary, depending on when they're reading, where they're reading and how they're feeling. Targeting these groups is instrumental in creating viral content, and these readers can be serious and well-informed people, even if the content they choose at these times is not. BuzzFeed editor-in-chief Ben Smith says: "I think mostly everybody, except sociopaths, cares about cute animals and most people want to know what's going on in the world... College kids who are in Boston or New York or LA, who were probably getting their news from The Crimson or The New York Times, or the Journal were the ones who were sharing and reading the ' 31 Animals Who Are Disappointed In You'."

So while the year's most viral stories might be light-hearted listicles or cute videos, excellent investigative (and other) content abounds, both online and in print formats - in fact, early 'soft' players like BuzzFeed are increasingly using the revenue from their huge audience base to finance hard-hitting long-form investigative work and social-issues reporting. And, as the Reuters Digital News Project (2016, p. 7), which surveyed consulted 30 journalists/editors from newsrooms in eight countries, found: "the most sophisticated audience teams are keenly aware that analytics are not perfect". Any analysis needs to be tailored to the goals and priorities of a newsroom and qualitative judgement, and there is strong evidence that this is being done. News organisations have used this judgement to quarantine seasoned investigative reporters from many of the staffing cuts, on the understanding that good investigative work drives subscriptions because it is scarce as well as socially valuable. 
All writers of course operate within the confines of an attention economy and there is now a clear onus or all reporters - perhaps especially investigative reporters, whose work is more resource-intensive - to justify the importance of a story, internally and externally. Major investigations are now packaged up with audiences in mind and marketed as big-ticket news items; the process of having to articulate (first to an editor, then to an audience) why a story is compelling, important and meaningful, can serve to make the narrative stronger and more accessible.

\section{To what extent is this being influenced or led by a shift from hardcopy publications to online outlets?}

Much commentary about the media pits print and online formats against each other. Certainly outlets like BuzzFeed are teaching legacy media outlets a thing or ten about getting an audience's attention online — and many of them are covering entirely new things (or old things in exciting new ways). They're also redefining old concepts like rounds reporting to generate more diverse coverage of LGBTI issues/identity or race/ethnicity and delivering niché, new and disruptive content. However, web platforms are simultaneously learning key lessons from print publishers and branching into traditional territory by setting up investigative teams or hiring experienced writers to generate solid long-form coverage; heavyweight print imprints are still important agenda-setters; and there are examples of print outfits that, beyond just surviving, are thriving. Importantly, the distinction between hardcopy and online publications is no longer a clear one; most print publications maintain a substantial digital presence (or even a range of web and social platforms), and some online-first publications collect their most enduring content into print collections. However, in 
researching Writing Feature Stories, we did find some broad distinctions in style and content across the three major platforms for features: newspapers, magazines and online. We have analysed this through the lens of the news values each emphasises.

\section{Newspaper feature stories}

The identity of most newspapers is still bound to ideas of credibility and objectivity, which influence the style and content of newspaper features. First-person feature articles are less common in the news pages, unless they are marked as 'opinion' or ‘commentary' (although Johnston \& Graham's 2013 study of the formats of Australian newspapers from 2007-11 found an increase in commentary stories in newspapers generally, and instances of opinion within inverted-pyramid reporting). Colloquialisms and slang are still uncommon in newsprint features, which generally centre on stories that sit within the news agenda of the mainstream media- that is, those tied to the news values of impact, prominence and conflict. Nevertheless, human interest and colour features are also common, and proximity is also a core in newspaper editorial decisions.

\section{Magazine feature stories}

Naturally, the visual elements of storytelling are important in magazines, and this influences content. Publications carefully craft their aesthetic, whether in photographs, typography or layout and magazine features contain more break-out elements. While both newspapers and magazines use graphics (like infographics and timelines), the longer production deadline allows magazines to place a higher emphasis on these visuals. 
Traditionally, magazines have been more audience-focused than newspapers, and create a culture based around readership, with currency as a central news value. There is also a premium on the human-interest value of stories and a tendency to focus on the emotional impact of events. However, the lines between magazines and online publishing venues are blurring, as hard-copy publications move online altogether, or launch web and tablet versions of their print products, complete with interactive and multimedia elements. There is also an emerging 'slow journalism' movement that positions itself somewhere between a newspaper, a magazine and a history book. Publications like Delayed Gratification and Monocle are magazines in format but have a distinct news(paper) style and focus, and publish monthly, bi-monthly or even quarterly, picking up news and investigative stories that can be overlooked in the 24hour news cycle.

\section{Online feature stories}

Online publishing has already dramatically altered how we write and how we read feature stories but long-standing styles and structures of feature writing still apply to online publication. One key difference, though, is writing tone, which skews casual, direct and personal and deploys identification, second-person, questions and slang.

Brevity is valued in an online landscape but there is scope for long-form work. For example, 'digitally native' business news site Quartz's editor, Kevin Delaney (in Marshall, 2013), avoids articles between 500 and 800 words, advocating instead for very short or long-form online features. To combat the real or perceived lack of reader focus, however, digital features tend to use structural elements to help readers 
navigate slabs of text. Headings, subheadings and even article summaries or bullet points play to readers' 'inspectional reading' habits.

Carroll (2010) suggests the simple fact that an article has been printed in a newspaper or magazine gives it some credibility and currency that isn't always available to online feature writers. Consequently, online features have to show readers their context and purpose more clearly, quickly and explicitly. The staple news values of impact, prominence and novelty are priorities for online features, but timeliness is possibly the most important. Currency is also important, because the internet is such a maker and promoter of cultural icons. On a related note, the nature of proximity is vastly different online. Where newspapers may define proximity geographically, websites create cultural communities around shared interests, professions and associations. The mark of a good journalist used to be an intimate knowledge of their city and its secrets, but in many web contexts, journalists are culture brokers, and it is knowledge of their sub-topics and interests that is important.

\section{What is it that attracts journalism students to feature writing, particularly in softer forms, than news?}

In our experience, what has always attracted journalism students to feature writing is the writing. The inverted pyramid structure central to news reporting is a counterintuitive way to go about things, but once mastered, it is a form of writing that is, well, formulaic. No journalist we know has ever finished the day's work with the words, "I'm so happy with the way I wrote that news story". Their satisfaction will be 
reserved for the news in their news story. Feature writing opens the door to a broader range of writing styles and approaches, which appeals both to those with literary aspirations and those who want to express their opinions on the issues of the day.

Here, too, there has been a marked change in the past few decades, for better and for worse. When Matthew began in journalism in 1981 print was still the dominant newsgathering medium and beginning journalists were bluntly told by crusty old subeditors that readers couldn't give the proverbial rat's tossbag about their views. The story is what counts, not you. If and when you get to write a column, then you can use the perpendicular pronoun 'I' but that'll be in about a decade's time. This newsroom culture shifted dramatically over time (to the extent that first-person reporting is encouraged by many publications) but focusing on a story while isolating your views from the process remains an important discipline to learn, both in reporting news and in writing features. It is worth asking students to consider any issue about which they feel strongly, such as climate change, gender identity, racism or asylum seekers, and ask questions about it from as many perspectives as possible, including — especially, even — those they disagree with. All the new information they gather may not change their view on the issue, but it might. And at the very least they will know a good deal more about the subject; this can be passed on to readers. Exploring a range of perspectives is not the same as false balance, which is the notion that both sides of a debate must always be put, regardless of the issue at hand. Gathering new information has always been a good discipline to acquire, but it is also not natural to ask students to suppress their views and feelings in their work because writing is an act of self-expression. Habitually withholding your views can lead to censoring yourself. How a student as a person responds to the events, issues and 
people they encounter can, or should, fuel their journalism.

Most journalism students, then, want to express themselves in their stories, and they need to acquire the discipline of learning about the world beyond their views and their experiences. It takes a while to learn both and so they particularly struggle with the question of when and how to include themselves openly in their stories. Being alive to your emotional and intellectual responses does not equate to including them in each and every feature you write. Sometimes, the subject of the story is more important than your response to it. A famous example here is John Hersey's report on the dropping of the first atomic bomb, on Hiroshima, in 1945, which instantly killed more than 100,000 people, the majority of them civilians. When Hersey visited the bombed city the following year to interview survivors, he felt a 'kind of horror', but this prompted him to reflect: if this is how I feel eight months after the bomb, what must those in the city on the day have felt? (Ricketson, 2015). Rather than express directly in his story what he felt, Hersey channelled that emotion and energy into enabling the reader, as far as possible, to sympathise with the experience of the bomb's survivors.

Not all stories, obviously, are as emotionally charged as Hiroshima, and there are many where a student's thoughts and feelings are relevant and will inform the story. A good first question for students to ask about when to include themselves in their features is: what is my stake in this story, and will my presence improve it? Answering that question requires them to consider the subject of the story and its audience. On this it seems clear that readers' tastes have changed in the past three decades. They are more literate about the practices of the news media. They seek out columnists because it is easier to connect with the individual voice of a columnist 
than with the institutional voice of straight news, which is at best formal and dry and, as alluded to earlier, locks in a small box any colour, tone or nuance in the writing. Equally important, we need to recall how and where young people find their way into the media today compared to the 1980s. Mainstream media companies have shrunk in the first decades of the twenty-first century, and where freelancers once comprised a minority, now they are, if not a majority, a growing proportion of the total journalistic workforce. Beginning journalists now need to be able to write across a range of genres: news, colour, analysis, opinion, personal blog, Twitter, listicles and so on. The days of the ten-year wait are over.

\section{References}

Bell, E. (2016, March 7). Facebook is eating the world. Columbia Journalism Review. Retrieved from https://www.cjr.org/analysis/facebook and media.php

Carroll, B. (2010) Writing for Digital Media. Hoboken: Taylor and Francis.

Cherubini, F. \& Nielsen, R. K. (2016) Editorial Analytics: How news media are developing and using audience data and metrics - Digital News Project 2016, University of Oxford: Reuters Institute for the Study of Journalism. Retrieved from https://reutersinstitute.politics.ox.ac.uk/sites/default/files/research/files/Editorial\% 252 0analytics $\% 2520$ -

$\% 2520$ how $\% 2520$ news $\% 2520$ media $\% 2520$ are $\% 2520$ developing $\% 2520$ and $\% 2520$ usi ng\%2520audience $\% 2520$ data $\% 2520$ and $\% 2520$ metrics.pdf

Glover, S. (1999) Secrets of the Press: Journalists on Journalism. London: Allen Lane.

C. Haik, (2014, December) 'The year of the reader', Nieman Lab: Predictions for Journalism 2015, Retrieved from www.niemanlab.org/2014/12/the-year-of-the$\underline{\text { reader/ }}$

Hurst, J. (1988). The Walkleys: Australia's best journalists in action. Victoria: John Kerr.

Johnston J. and Graham, C. (2013) 'Shifting patterns in Australian newspaper writing styles’, Australian Journalism Review, 35 (2), pp. 117-31.

Keefe, P. R. (2013, November 25) 'Rocket man', The New Yorker, pp. 48-61. 
Marshall, S. (2013, October 15) 'Why Quartz does not publish 500 to 800 word articles', journalism.co.uk. Retrieved from www.journalism.co.uk/news/-smartdenwhy-quartz-does-not-publish-500-to-800-word-articles/s2/a554444/

MEAA (2018, April). Media, Entertainment and Arts Alliance submission to the Australian Competition and Consumer Commission's DIGITAL PLATFORMS INQUIRY. Retrieved from https://www.meaa.org/download/meaa-submission-to-theaccc-inquiry-into-digital-platforms/

Murphy, K. (2018) On Disruption. Carlton: Melbourne University Press.

Newman, N. and Levy,D. (2014) Reuters Institute for Digital News Report 2014, University of Oxford, Retrieved from https://reutersinstitute.politics.ox.ac.uk/sites/default/files/Reuters\%20Institute\%20Dig ital $\% 20$ News $\% 20$ Report $\% 202014$.pdf

Ricketson, M. (2004) Writing Feature Stories: How to research and write newspaper and magazine articles. Crows Nest: Allen \& Unwin.

Ricketson, M. (2015) When slow news is good news: Book-length journalism's role in extending and enlarging daily news, Journalism Practice, 4, pp. 1-14.

Ricketson, M., \& Graham, C. (2017, 2nd ed.) Writing Feature Stories: How to research and write articles - from listicles to longform. Crows Nest: Allen \& Unwin.

Rogers, S. (2010, Friday 13) 'Florence Nightingale, datajournalist: information has always been beautiful', The Guardian. Retreived from

https://www.theguardian.com/news/datablog/2010/aug/13/florence-nightingalegraphics

Schugart, A. (2018, January 2) 'The Best in Interactive Multimedia Journalism 2017: Pushing the Limits of Storytelling', Medium. Retrieved from https://medium.com/@aschugart/the-best-in-interactive-multimedia-journalism-2017pushing-the-limits-of-storytelling-e2ccdec8e 576

Sherwood, M., Zion, L., \& O'Donnell, P. (2016). Where do journalists go after newsroom job cuts? Journalism Practice, 10(1), 35-17.

Thompson, D. (2014, June 17) 'Why audiences hate hard news - and love pretending otherwise', The Atlantic. Retrieved from www.theatlantic.com/business/archive/2014/06/news-kim-kardashian-kanye-westbenghazi/372906/

Topping, S. (2014) 'The prizes', The Pulitzer Prizes. Retrieved from www.pulitzer.org/administration\#journcats. 